\title{
Görme Engelliler için Erişilebilir bir Etkinlik Alanı olarak Engelsiz Filmler Festivali*
}

\author{
Accessible Film Festival as an Accessible Domain for the Blind and Partially Sighted \\ People
}

Araştırma/Research

\section{Duygu DALASLAN**, Pelin ŞULHA***}

* Arş. Gör., Adana Alparslan Türkeş Bilim ve Teknoloji Üniversitesi, İnsan ve Toplum Bilimleri Fakültesi, Mütercim-Tercümanlık Bölümü, e-posta: duygudalaslan@gmail.com, ORCID ID: orcid.org/0000-0003-46764682

** Dr. Öğr. Üyesi, Dokuz Eylül Üniversitesi, Edebiyat Fakültesi, Mütercim-Tercümanlık Bölümü, e-posta: pelin.sulha@deu.edu.tr, ORCID ID: orcid.org/0000-0002-0515-141X

\section{ÖZET}

Ankara Engelsiz Filmler Festivali 2013 yılından itibaren engelli bireylerin kültürel ve sanatsal faaliyetlere katılmalarını sağlamak amacıyla düzenlenmeye başlamıştır. 2017 yılına kadar sadece Ankara'da yaşayan engelli olan ve olmayan sinemaseverleri bir araya getiren bu festival aynı yıl Puruli Kültür Sanat'ın İstanbul ve Eskişehir'i de gündemine almasıyla daha çok sayıda engelli seyirciye erişim fırsatını yakalamıştır. Bu çalışmanın amacı, Engelsiz Filmler Festivali'nin görme engelli hedef kitlesi açısından ne derece erişilebilir olduğunu ortaya koymaktır. Bu amaca uygun olarak, festivalin Ankara'da düzenlenen kısmı örneklem olarak seçilmiştir. Bunun sebebi, festivalin sürekli olarak Ankara'da düzenleniyor olması ve festival burada daha uzun sürdüğü için diğer şehirlere kıyasla Ankara'nın veri toplama açısından daha uygun olmasıdır. Araştırma üç basamaktan oluşur. illk olarak, festivalin hedef kitleye nasıl ve hangi yollarla duyurulduğu araştırılmıştır. İkinci olarak, önce festival posteri, kılavuzu ve gösterim programının tanıtıldığı kitapçı̆̆ın hedef kitleye nasıl ulaştıııldığı incelenmiş, ardından saha çalışması kapsamında izleyiciler, festivale katılım oranları ve gösterdikleri ilgi açısından gözlemlenmiştir. Üçüncü olarak, festivalin basında nasıl yankı bulduğu araştırılmış ve görme engelli hedef kitlenin festivaldeki sesli betimlemeler hakkında görüşlerinin alındığı ankete yer verilmiştir. Bu araştırma sonucunda festivalin basında, sosyal medyada, internet sitelerinde ve mail gruplarında paylaşıldığı görülmüştür. Festival posterinin, kılavuzunun ve gösterim programının tanıtıldığı kitapçığın görme engelliler için erişilebilir nitelikte olduğu gözlemlenmiştir. Saha araştırmasında ise, görme engelli

"Bu makale, Duygu DALASLAN tarafından Dokuz Eylül Üniversitesi, Sosyal Bilimler Enstitüsü, Çeviribilim Doktora Programında Dr. Öğr. Üyesi Pelin ŞULHA danışmanlığında yürütülen ve devam eden doktora tezinden üretilmiştir. 
katılımcıların sayısının az olduğu tespit edilmiştir. Öte yandan, engelli olmayan katılımcıların görme engellilerin de film izleyebileceklerini bilmediği gözlemlenmiştir. Festivalin basında "fark yaratanlar" olarak yer aldığı göze çarpmaktadır. Görme engellilere uygulanan ankette ise, festivalde yer alan sesli betimlemeli filmlerin görme engellilerin beklentilerini karşıladığı belirlenmiştir. Araştırmanın sonuçlarına göre, festival görme engelli hedef kitlesi için erişilebilir niteliktedir. Bu çalışma hem görme engellilere yönelik hedef kitle odaklı bir çalışma olması hem de görme engellilerin görüşlerinin yanı sıra gören izleyicilerin de sesli betimlemeye yaklaşımlarını ortaya koyması bakımından bir ilk olduğu için önemlidir.

Anahtar Sözcükler: görme engelli, erişilebilirlik, sesli betimleme, engelsiz filmler festivali

\section{ABSTRACT}

Ankara Accessible Film Festival has been organized since 2013 to encourage the participation of individuals with disabilities in cultural and artistic activities. Until 2017 this festival has brought together the disabled and non-disabled cinema lovers living in Ankara, but after Puruli Culture \& Arts had placed Istanbul and Eskişehir on its agenda in the same year it had the opportunity to reach more people with disabilities. The aim of this study is to determine the extent to which the Accessible Film Festival is accessible to the blind and the partially sighted target audience. For this purpose, the part of the festival organized in Ankara was chosen as a sample. This is due to the fact that the festival has been held in Ankara continuously since the beginning and that data collection is more suitable as the festival lasts longer in Ankara than in other cities. The research consists of three steps. Firstly, in what ways the festival has been announced to the target audience was investigated. Secondly, how the festival poster, the guide and the booklet which included the program have been introduced to the target audience was explored, and then, in the scope of the fieldwork, the audience was observed in terms of their participation rates and their interests. Thirdly, it was searched how the festival was reverberated in the press and a survey was given to the blind and the partially sighted target group to learn their opinions about the audio descriptions. According to the results obtained from these research steps, it was concluded that the festival was shared in the press, social media, and web sites and in the mail groups. It was observed that the festival poster, the guide and the booklet including the program were accessible to the blind and the partially sighted viewers. In the field study, it was found that the number of the blind and the partially sighted viewers was low. On the other hand, it was observed that nondisabled participants did not know that the blind and the partially sighted viewers could also watch movies. The festival was announced in the press as a "change maker". In the survey, it was concluded that the films with audio descriptions in the festival fulfilled the expectations of the blind and the partially sighted viewers. According to the findings of the study, the festival is accessible enough for the blind and the partially sighted target group. This study is important because it is the first study which focuses on the blind and the partially sighted target audience, and reveals both the opinions of the blind and the partially sighted participants and the attitudes of the non-disabled audience towards audio description.

Keywords: the blind and the partially sighted, accessibility, audio description, accessible film festival

\section{Giriş}

Film festivalleri, sinemaseverlerin bir araya gelerek insan hakları, toplumsal cinsiyet gibi belli temalara göre seçilmiş filmleri izlediği yerlerdir. Film festivallerinde film gösterimleri yapılmasının yanı sıra izleyiciler yapımcı, yönetmen ve aktörlerle bir araya gelerek sahneleri, rolleri ve iletilmek istenen mesajları tartışırlar. Türkiye'de düzenlenen 
festivaller arasında ilk akla gelenler, !F - Bağımsız Filmler Festivali, İstanbul Film Festivali, Antalya Altın Portakal Film Festivali ve Adana Altın Koza Film Festivali'dir. Bu festivallerde göze çarpan en önemli sorun erişilebilirliktir. Bu soruna sadece Türkiye'de değil dünyada pek çok ülkede rastlanmaktadır. Erişilebilirlik, engelli bireylerin görselişitsel materyallerden yararlanmalarını sağlayan her türlü uygulamayı kapsayan bir kavramdır. Teknolojik gelişmelerle birlikte, "Birleşmiş Milletler Engelli Hakları Sözleşmesi gibi uluslararası girişimler, sivil toplum kuruluşlarının ve derneklerin yaygınlaşması ve etkili hâle gelmesi ile" (Okyayuz \& Kaya, 2016, s. 16) erişilebilirlik kavramı, birçok bilimsel alanda araştırma konusu olmuştur. Görsel-işitsel çeviri şemsiyesi altında, sağırlar ve işitme engelliler için işaret dili ve alt yazı uygulamalarıyla görme engelliler için sesli betimleme uygulamaları yer alır. "Engelsiz erişim" kavramını tercih eden Şerife Dalbudak ise bu terimi "fiziksel bir engel yüzünden (örneğin, görme, işitme engeli) bir kaynak metne erişimi olmayan bireylere erişim sağlamak için yapılan çeviri türlerinin hepsi" olarak tanımlar (2019, s. 62). Bu makalede kullanılan "erişilebilirlik" kavramı, görme engeli olan ve olmayan tüm izleyicilerin bir araya gelerek, aynı anda o festivale katılması ve festivaldeki tüm etkinliklerden eşit derecede yararlanabilmesi anlamına gelmektedir. Bir filmin görme engelli izleyici kitlesi için erişilebilir hâle getirilmesi, o filmde, başta karakterler, nesneler, mekânlar, eylemler, jestler ve mimikler gibi görsel öğelerin sesli olarak aktarılması veya betimlenmesi demektir. Bu tekniğe "sesli betimleme" adı verilmektedir.

Roman Jacobson, çeviriyi üç şekilde sınıflandırır. Diliçi çeviri dilsel göstergelerin başka göstergelerle, diller arası çeviri dilsel göstergelerin başka bir dildeki göstergelerle, göstergeler arası çeviri ise dilsel olmayan göstergelerin dilsel göstergelerle yorumlanmasıdır (1959, s. 233). Bu bağlamda, sesli betimleme görsel-işitsel çeviri türü olarak, hem diliçi hem de göstergeler arası çeviridir. Ayşe Şirin Okyayuz, bu noktayı şu şekilde açıklamıştır:

Sesli betimleme, farklı ürünlere de eklenebilir. Örneğin, sesli betimleme metni, dublajı yapılmış yabancı bir filme; ana dili sesli betimleme dili ile aynı olan bir filme; yabancı bir görsel-işitsel ürüne, ikinci bir dilde sesli betimleme metni eklenebilir ve benzeri uygulamalar yapılabilir. Bu gibi örneklerden yola çıkarak, sesli betimlemenin hem diliçi hem de dillerarası/kültürlerarası bir çeviri türü olduğu, ayrıca, çok ortamlı bir uygulamasının olduğu açıktır. $(2017$, s. 566)

Bir çeviri türü olarak sesli betimleme, görsel ve işitsel öğelerin ön planda olduğu dünyayı erişilebilir kılar. Görsel-işitsel öğelerin ağırlıkta olduğu türlerin başında kültürel yaşamın bir parçası olan filmler gelir. Sesli betimleme yapılmadan önce görme engelli bireyler filmlere sadece işitsel kodlar yoluyla erişebiliyorlardı. Ancak bu türden kısıtlı bir erişim kendileri için yeterli olmuyordu. Bazen çevreden de yardım alıyorlardı ancak bu yardım profesyonel nitelikte olmadığı gibi bireyin bağımsız bir şekilde o filmden yararlanmasına olanak vermiyordu. Bu durum da, görme engelli bireylerin toplumsal ve kültürel hayatın dışında kalmalarına neden oluyordu. Sesli betimlemeyle beraber, görme engelli bir birey erişmek istediği filmin anlatısını daha iyi kavrar ve o filmden kendi payına ne almak istiyorsa onu alır. Bu açıdan, Nurhan Baş sesli betimlemeyi "filme iyi niyetli 
yapılan zorunlu bir müdahale" (2016, s. 171) olarak yorumlarken, Mine Güven ise "sözel göstergelerin başka göstergelerle etkileşim içinde bulunduğu bir iletişim biçimi" (2018, s. 108) olarak değerlendirir. Okyayuz ve Kaya ise "bir görsel-işitsel ürünün görsel kanalına erişimi olmayan kişilerin erişimini sağlamak için geliştirilen tekniğe verilen isimdir" $(2016$, s. 18) olarak tanımlar. En geniş tanımı yapan Nilgin Tanış Polat, sesli betimlemenin "görsel öğelerin tasvir edilmesi yoluyla görme engelli izleyicinin film, televizyon programı, tiyatro oyunu, video oyunu ya da müze sergisi gibi görme odaklı etkinlikleri izleyebilmesi için yapılan çeviri” olduğundan bahseder $(2009$, s. 3).

Sesli Betimleme Derneği, Türkiye'ye sesli betimleme çalışmalarını getiren ve bu çalışmaları aktif olarak sürdüren kurumdur. 2013'ten bu yana Puruli Kültür Sanat organizasyon şirketi tarafından düzenlenen Engelsiz Filmler Festivali'nde gösterilen filmleri, görme engelli hedef kitlesi için sesli betimlemeli olarak erişilebilir hâle getirmektedir. Festivalin amacı, engelli olan ve olmayan tüm izleyicilerin ortak bir alanda buluşarak, kültürel etkinliklere hep beraber katılmalarını sağlamaktır.

Bu çalışmanın amacı, 17-21 Ekim 2018 tarihleri arasında Puruli Kültür Sanat ve Sesli Betimleme Derneği'nin işbirliği çerçevesinde Ankara'da düzenlenen Engelsiz Filmler Festivali'nin görme engelli hedef kitlesi açısından ne kadar erişilebilir olduğu sorusuna cevap vermektir. Bu amaca uygun olarak, festival alanında bir saha çalışması yapılmıştır. Çalışma üç araştırma basamağına ayrılmıştır. İlk olarak, festivalin Puruli Kültür Sanat tarafından hedef kitleye nasıl ve hangi yollarla duyurulduğu ele alınmıştır. Ikinci olarak, festivalle ilgili materyallerin erişilebilirliği incelenmiş, festival alanında düzenlenen etkinlikler ve görme engelli olan ve olmayan katılımcılarla ilgili gözlemler yapılmıştır. Üçüncü olarak, festival sonrasında, festivalin basında nasıl yankı bulduğu incelenmiş ve görme engelli hedef kitleye Sesli Betimleme Derneği tarafından yapılan sesli betimlemeler konusunda bir anket yapılarak görüşleri alınmıştır. Bu çalışma neticesinde, erişilebilirliğin nasıl sağlandığı ve yapılan çalışmaların görme engelli hedef kitlenin beklentilerini ne ölçüde karşıladığı ortaya konmaya çalışılmıştır. Ülkemizde Baş (2019) tarafından engelli olmayan Mütercim-Tercümanlık Bölümü öğrencileriyle yapılan iki aşamalı alımlama çalışmasında Değirmen filminin yirmi dakikalık bir kesiti ele alınmıştır. İlk aşamada öğrencilerden filmin bu kesitinin sesli betimlemeli hâlini izleyip, anladıklarını yazmaları istenmiştir. İkinci aşamada da aynı kesitin betimlemesiz, orijinal hâlini izleyip anladıklarını yazmaları istenmiştir. Böylece, bir filmin betimlemeli hâliyle betimlemesiz hâlini zihinde canlandırırken ne gibi farklılıklar olduğu ortaya konmuştur. Çalışmanın amacı, betimlemede dikkat edilmesi gereken noktalara gören bireylerin algıları üzerinden dikkat çekmektir. Bu çalışmanın neticesinde, "sahne geçişleri, mekânın belirtilmesi, konuşan kişilerin kısaca belirtilmesi, anlaşılmayan ortam seslerinin açıklanması, betimlemenin zamanı, yansız ifade, ipucu vermeme" $(2019$, s. 57) dikkat edilmesi gereken noktalar arasında yer alır. Bu makalenin çerçevesinde gerçekleştirilen alımlama çalışmasının amacı ise, hem ulusal hem de uluslararası çaptaki bir film festivalinde gösterilen filmler üzerinden, görme engelli hedef kitlenin betimlemeler konusunda fikirlerini alarak betimleme çalışmalarına katkıda bulunmaktır. 


\subsection{Sesli Betimleme Derneği}

Ülkemizde sesli betimleme 2006 yılında Boğaziçi Üniversitesi Mithat Alam Film Merkezi'nin çalışmalarıyla başladı. Aralık 1999'da Boğaziçi Üniversitesi bünyesinde, öğrencilerin bilinçli izleyici olmalarını sağlamak amacıyla kurulan ve bünyesinde çeşitli etkinlikler, söyleşiler, paneller düzenleyen Mithat Alam Film Merkezi'nde sesli betimleme çalışmaları, bir grup öğrencinin Boğaziçi Engelliler Birimi ve Engelsiz Erişim Grubu ile yaptığı gönüllü işbirliği sonucunda ortaya çıktı ${ }^{1}$. Grup, sırasıyla, Çarpışma, Cenneti Beklerken, Kayıp Balık Nemo ve Sis ve Gece adlı filmlerin sesli betimlemelerini yaptı. Bu çalışmalar, Sesli Betimleme Derneği'nin kurulmasına zemin sağladı. Bu dönemde Türkiye'de sesli betimleme yapan herhangi başka bir kurum olmamasından ötürü, Sesli Betimleme Derneği bir ilki gerçekleştirmiş oldu.

2010 yılında, kendi tabiriyle "birarada yaşama ilkesini hayata geçirme amacıyla" yola çıkmış olan Sesli Betimleme Derneği, ilk eğitimlerini Amerika Birleşik Devletleri Körler Federasyonu (ACB) Sesli Betimleme Proje Koordinatörü Dr. Joel Snyder'dan alarak profesyonel anlamda betimleme çalışmalarına başlamıştır. Amerika'da genel olarak sesli betimlemeye yaklaşım Synder'ın deyimiyle "ne görüyorsan onu söyle" yani ekranda ne görülüyorsa, onun sözel ifadelere dönüştürülmesi şeklindeyken, Avrupa'da eğilim öyküleştirme yönündedir. Jan-Louis Kruger öyküleştirme tekniğini "görsel kodların kendilerinden ziyade anlatısal etkilerine daha çok uyan bir anlatı yaratma" (2010, s. 233) olarak tanımlamaktadır. Avrupa'da daha çok tercih edilen öyküleştirme tekniğine örnek olarak Polonya ve İspanya ekolünden bahsedebiliriz. Sekiz ülkenin bir araya gelerek Avrupa'da sesli betimleme konusunda standartlaştırma yaratmak için oluşturduğu ADLAB projesi kapsamında, Polonya ekolü, karakterlerin ve eylemlerinin betimlemeleriyle efektler ve müzik betimlemeleri üzerinde durur. Betimleme yazarının bir karakteri anlatırken kısa, öz ve canlı ifadeleri tercih etmesi gerektiğini vurgular (2015, s. 22). Yine de kararı betimleme yazarına bırakan ekolün önerileri arasında "donup kalmak", "gözlerini dehşetle açmak" gibi ifadeler yer alır (2015, s. 23). İspanya ekolü ise betimlemelerle film türleri arasındaki sıkı bağa dikkat çeker. Filmlerin türlerine göre farklı görsel stilleri ve kendilerine özgü dillerinin olduğundan bahseder. Betimlemelerde bu ayrıntıların göz ardı edilmemesinin altını çizerek sahnelerin hissettirdiklerinin izleyiciye aktarılması gerektiğini savunur (2015, s. 29). Sesli Betimleme Derneği bu alanda Amerika'daki meslektaşlarıyla aynı yaklaşımı benimsemesine rağmen teknik kısıtlamalar kimi zaman buna izin vermeyebilir. Ayrıca derneğin ekip çalışmalarına kuruluşundan beri görme engellilerin dâhil olması erişilebilirlik kalitesi bakımından önemli bir katkıdır. Sesli Betimleme Derneği 2013 senesinden bu yana Engelsiz Filmler Festivali'ndeki tüm filmlerin sesli betimlemeli olarak erişilebilir hâle getirilmesinde aktif rol oynamaktadır².

\footnotetext{
${ }^{1}$ Mithat Alam Film Merkezi ile ilgili ayrıntılı bilgiye bu adresten ulaşılabilir: http://www.mafm.boun.edu.tr/kategori/48/sesli-betimleme-ogrenci-grubu ${ }^{2}$ http://www.sebeder.org
} 


\subsection{Engelsiz Filmler Festivali}

Festival, "Ankara Engelsiz Filmler Festivali" adı altında, "kültürel hayata eşit katılım ilkesiyle" Eylül 2013'te Puruli Kültür Sanat Şirketi tarafından düzenlenmeye başladı. Puruli Kültür Sanat, kendisini, "kültürel belleğe ve birikime uzun vadede değer katacak kalıcı projeleri hayata geçiren bir kültür operatörüdür. Yaygın dolaşıma dâhil olmayan sanatın, mümkün olduğu kadar fazla kişiye ulaşmasını amaçlar," ("Nedir", t.y.) olarak tanıtmaktadır.

2013 yılından bu yana düzenlenen Engelsiz Filmler Festivali'nin amacı "engelli bireylerin yakınlarıyla birlikte film izleyebilme, kültürel ve sosyal bir etkinliğe katılmalarını" sağlamaktır ("Hakkında”, t.y.). Festival kapsamında, görme engelli, işitme engelli ve ortopedik engellilerle otizmli bireyler ve aynı zamanda herhangi bir engeli bulunmayan seyirciler bir araya gelir. Festivalde Türkiye ve dünya sinemasının önde gelen uzun ve kısa metrajlı filmleri erişilebilir formatlarda gösterilir. Otizmli bireyler için ayrıca gösterimler yapılırken, görme ve işitme engelli bireyler için de özel atölyeler düzenlenir, yapımcı ve yönetmenler ise festivalde gösterilen filmleriyle ilgili olarak seyircilerle söyleşilere katılır.

2018 Engelsiz Filmler Festivali, İstanbul, Eskişehir ve Ankara'da düzenlendi. Festivale İstanbul'da Boğaziçi Üniversitesi SineBU Sinema Salonu ve Eskişehir'de Taşbaşı Kültür ve Sanat Merkezi, Ankara'da Çankaya Belediyesi Çağdaş Sanatlar Merkezi ve Goethe-Institut Ankara ev sahipliği yaptı. Festival mekânları rastgele seçilmemiştir. Her sene olduğu gibi, bu sene de tüm bu mekânların, önceki yıllarda alınan eleştirileri de göz önünde bulundurarak, engelli olan ve olmayan tüm bireylere hitap ediyor olmalarına dikkat edilmiştir.

\section{Engelsiz Filmler Festivali ve Erişilebilirlik}

\subsection{Festival Öncesi: Festivalin Hedef Kitleye Duyurulması}

Engelsiz Filmler Festivali 2018, basında geniş yer tuttu. T24, festival duyurusunu "Engelsiz Filmler Festivali 6. kez sinemaseverlerle buluşuyor" ${ }^{3}$ başlığıyla yaparken, haberde 2018'in programına yer verdikten sonra, festivaldeki erişilebilirlik uygulamalarına ve bunların Sesli Betimleme Derneği tarafından gerçekleştirildiğine de yer verir. Aynı şekilde, Milliyet Gazetesi de "Engelsiz Filmler Festivali Üç Şehirde" ${ }^{4}$ başlığıyla festivali duyururken festivaldeki etkinliklerin ücretsiz olduğunun altını çizerek, görme engelliler için festivaldeki filmlerin sesli betimlemeyle erişilebilir hâle getirileceğini belirtir. Habertürk, festival haberini "Engelsiz Filmler Festivali 6. kez sinemaseverlerle buluşuyor" ${ }^{5}$ başlığıyla vererek, festivalin daha önce de düzenlendiğine dikkat çeker, "kültürel hayata eşit katılımın yaygınlaşması amacı"na da vurgu yapar. Medyakafa adlı haber sitesi Engelsiz Filmler Festivalinin engelleri aşarak toplumdaki herkesi bir araya getirme çabalarının sadece otizmli bireylere yönelik olan kısmını ele alır

\footnotetext{
${ }^{3}$ https://t24.com.tr/haber/engelsiz-filmler-festivali-6-kez-sinemaseverlerle-bulusuyor,673939

${ }^{4}$ http://www.milliyet.com.tr/engelsiz-filmler-festivali-uc-gundem-2756707/

${ }^{5}$ https://www.haberturk.com/engelsiz-filmler-festivali-6-kez-sinemaseverlerle-bulusuyor-2093437
} 
ve festivalin duyurusunu "6. Engelsiz Filmler Festivali, Seyircilerini 'Otizm Dostu Gösterim'lerine Davet Ediyor" ${ }^{6}$ başlığıyla yapar. Timeturk de "Otizm dostu 'Engelsiz Filmler Festivali' başlıyor" ${ }^{7}$ başlığıyla "otizm dostu" noktasına vurgu yaparken, festival programındaki çocuklara yönelik çevre ve arkadaşlık üzerine animasyonların gösterimi, canlandırma atölyeleri gibi etkinliklerden bahseder.

İkinci olarak, Engelsiz Filmler Festivali'nin duyurusu, sponsorların başta Facebook, Twitter ve Instagram olmak üzere sosyal medya hesaplarından "engellerin ve sınırların aşılmak için var olduğunu gösteren yapımlar” başlığıyla ön plana çıkarılarak yapıldı. Üçüncü olarak, Sesli Betimleme Derneği'ne ait, görme engellilerle sesli betimlemeli filmlerin listesini paylaşan ve aynı zamanda da engelliler arasında bir tartışma platformu olan “Betimleme Tartışmaları” mail grubunda da duyurusu yapıldı.

\subsection{Festival Alanında Yapılan İncelemeler Metinler}

Festivale ait tüm metinlere sosyal medya hesaplarında yer verilmiştir. Ayrıca, Braille alfabesi ile basımları yapılmıştır. Öte yandan, festival alanında bulunan görevlilerin, hedef kitleyle tek tek ilgilendikleri, etkinliklerle alakalı tüm sorularına cevap vermeye çalıştıkları gözlemlenmiştir.

\section{Afiş ve Kılavuz}

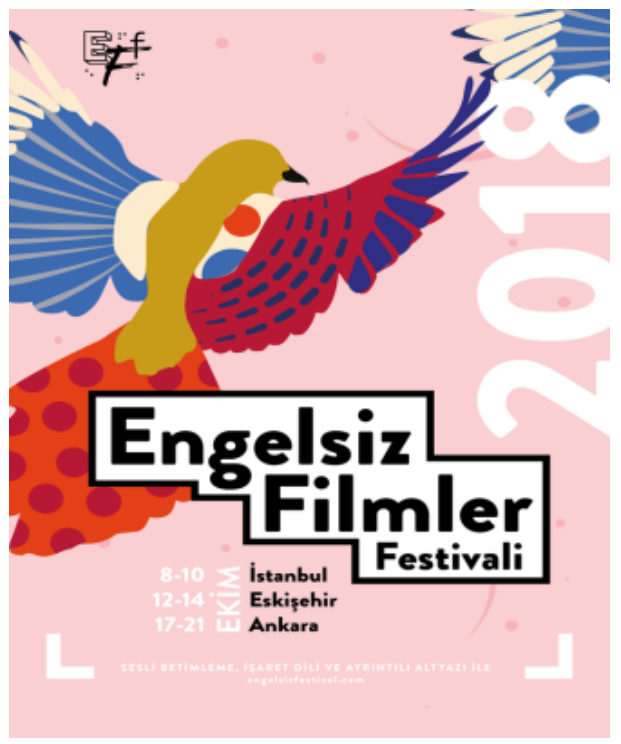

Resim 1. Engelsiz Filmler Festivali 2018

\footnotetext{
${ }^{6}$ https://www.medyakafa.com/eglence/otizm-dostu-gosterim/

${ }^{7}$ https://www.timeturk.com/otizm-dostu-engelsiz-filmler-festivali-basliyor/haber-952526 
Festivale ait afiş ve kılavuzun kapağının dış tasarımı Resim 1'de gösterilmiş olduğu gibi aynıdır. Engelsiz Filmler Festivali'ne ait sosyal medya hesabında bu görsel şu şekilde betimlenmiştir:

ENGELSiZ FILMLER FESTIVALi 2018/AFiş BETiMLEMESi: Dikdörtgen formda ve davetiye tarzında tasarlanmış. Canlı; rengarenk..Şeker pembesine yakın lila renkteki fonunun bir bölümünde koyu tonda küçük yuvarlaklar ve hilale benzeyen desenler var. Afişte solda rengârenk bir kuş, sağda daha geniş bir alanda festivalin adı-yılı, gösterimlerin yapılacağı şehirler, mekânlar ve tarihler yer alıyor. Detaylar şöyle: "8-10 EKiM, İstanbul-SineBU”, "12-14 EKiM, Eskişehir-Kırmızı Salon”, "1721 EKiM, Ankara-Çağdaş Sanatlar Merkezi, Goethe-Institut Ankara". Uçuyormuş gibi kanatları açık olan kuşun kısmen arkası dönük. Sağ profilden görülüyor, sol kanadının ucu kenarda ve kuyruğunun ucu köşede kaldığından görünmüyor. Yüzü ve pastel turuncu üzerine koyu pembe büyük beneklere sahip kuyruğunun küçük bir kısmına kadar olan yeri hardal renginde. Kapalı tuttuğu gagası kömür karası bir tonda. Kanatları beyaz, turuncu, açık-koyu mavi ve gri rengi barındırıyor ve bu halleriyle vücudunun en dikkat çeken yerleri. Festivalin yılı, beyaz ve içi dolu büyük rakamlarla sondan başlayarak dikey olarak yazılmış ve sağ kenarı olduğu gibi kaplamış. Hemen hemen ortaya konumlandırılmış "Engelsiz Filmler Festivali” adı, üzeri kapalı bir merdiveni andıran beyaz bir kutucuğun içinde. Sadece baş harfleri büyük. Her bir kelime üstündekinin dördüncü harfinin altından başlayacak şekilde ve son kelimesi daha küçük puntolu olarak yazılmış. Festivalin adı ve kutucuğun hatları kuşun gagasıyla aynı renk. Gösterimlerin yapılacağı tarih, şehir ve salonlar siyah ve beyaz harflerle kutucuğun altında, sağda yer alıyor. Tarihler ile diğer bilgiler, sondan başlayarak dikey biçimde konumlandırılan büyük beyaz harfli "EKiM" vurgusuyla birbirinden ayrılmış ("engelsizfestival”, 2018).

\section{Gösterim Programı}

Festivale ait tüm etkinliklerin yer aldığı gösterim programına hem sosyal medya hesaplarından hem de salonların girişlerinden erişilebiliyor. Görme engeli bulunmayan izleyicilere yönelik hazırlanmış olan program görseli aşağıdaki gibidir: 


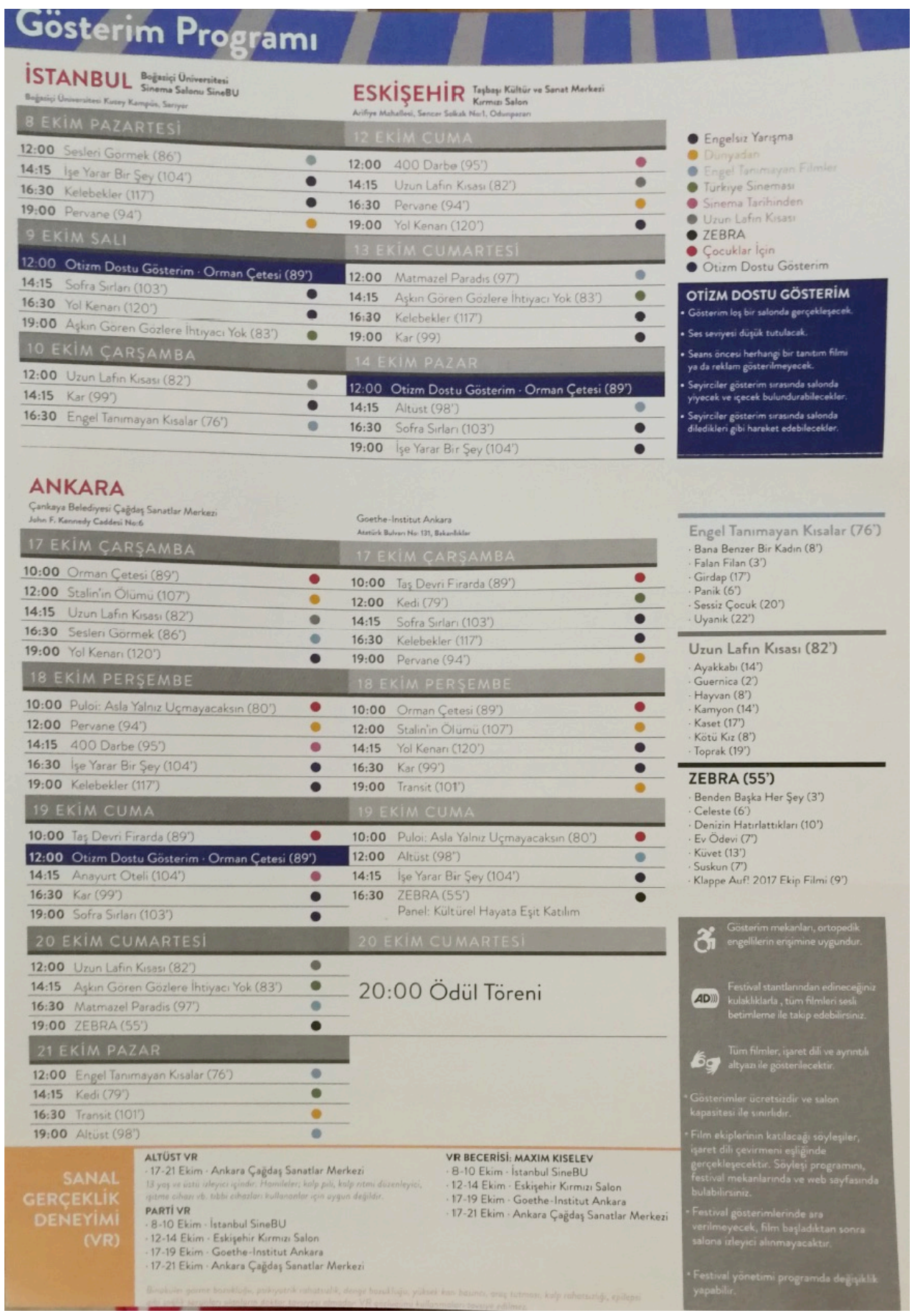

Resim 2: 2018 Engelsiz Filmler Festivali Basılı Gösterim Programı 
Ancak, gösterim programının betimlemesi herhangi bir yerde bulunmamaktadır. Görme engelli izleyici kitlesine yönelik olarak gösterim programına festival sayfasında word ve $p d f$ formatlarında aşağıdaki gibi erişilebilir:

Gösterim Programı

İstanbul

Boğaziçi Üniversitesi SineBU

8 Ekim Pazartesi 12.00 Sesleri Görmek, 14.15 işe Yarar Bir Şey, 16.30 Kelebekler, 19.00 Pervane

9 Ekim Salı 12.00 Otizm Dostu Gösterim: Orman Çetesi, 14.15 Sofra Sırları, 16.30 Yol Kenarı, 19.00 Aşkın Gören Gözlere İhtiyacı Yok 10 Ekim Çarşamba 12.00 Uzun Lafın Kısası, 14.15 Kar, 16.30 Engel Tanımayan Kısalar

\author{
Eskişehir \\ Taşbaşı Kültür Sanat Merkezi Kırmızı Salon \\ 12 Ekim Cuma 12.00 400 Darbe, 14.15 Uzun Lafın Kısası, 16.30 Pervane, 19.00 Yol Kenarı \\ 13 Ekim Cumartesi 12.00 Matmazel Paradis, 14.15 Aşkın Gören Gözlere ihtiyacı Yok, 16.30 Kelebekler, 19.00 Kar \\ 14 Ekim Pazar 12.00 Otizm Dostu Gösterim: Orman Çetesi, 14.15 Altüst, 16.30 Sofra Sırları, 19.00 işe Yarar Bir Şey \\ Ankara \\ Goethe-Institut Ankara \\ 17 Ekim Çarşamba 10.00 Taş Devri Firarda, 12.00 Kedi, 14.15 Sofra Sırları, 16.30 Kelebekler, 19.00 Pervane \\ 18 Ekim Perşembe 10.00 Orman Çetesi, 12.00 Stalin'in Ölümü, 14.15 Yol Kenarı, 16.30 Kar, 19.00 Transit \\ 19 Ekim Cuma 10.00 Puloi: Asla Yalnız Uçmayacaksın, 12.00 Altūst, 14.15 İşe Yarar Bir Şey, 16.30 ZEBRA, 17.30 Kültürel Hayata Eşit Katılım Pan \\ Ankara \\ Çankaya Belediyesi Çağdaş Sanatlar Merkezi \\ 17 Ekim Çarşamba 10.00 Orman Çetesi, 12.00 Stalin'in Ölümü, 14.15 Uzun Lafın Kısası, 16.30 Sesleri Görmek, 19.00 Yol Kenarı \\ 18 Ekim Perşembe 10.00 Puloi: Asla Yalnız Uçmayacaksın, 12.00 Pervane, 14.15 400 Darbe, 16.30 işe Yarar Bir Şey, 19.00 Kelebekler \\ 19 Ekim Cuma 10.00 Taş Devri Firarda, 12.00 Otizm Dostu Gösterim: Orman Çetesi, 14.15 Anayurt Oteli, 16.30 Kar, 19.00 Sofra Sırları \\ 20 Ekim Cumartesi 12.00 Uzun Lafın Kısası, 14.15 Aşkin Gören Gözlere ìntiyacı Yok, 16.30 Matmazel Paradis, 19.00 ZEBRA \\ 21 Ekim Pazar 12.00 Engel Tanımayan Kısalar, 14.15 Kedi, 16.30 Transit, 19.00 Altüst
}

Resim 3: 2018 Engelsiz Filmler Festivali Word Formatında Gösterim Programı

\title{
2.2.1 Festivaldeki Etkinliklerin İncelenmesi
}

Salonlarda filmler orijinal sesleriyle gösterildi çünkü bu festivalin amacı görme engellilere olduğu kadar gören izleyicilere de hitap etmektir. Sesli betimlemeli olarak filmlere erişmek isteyen izleyiciler, salon girişlerinde kulaklıkları temin edebildiler. 17 Ekim 2018 tarihinde, festivalin ilk günü, Çağdaş Sanatlar Merkezi'nde gerçekleşen gösterimlere ve etkinliklere görme engellilerden katılan kimse olmadı.

18 Ekim 2018 tarihinde, festivalin ikinci günü, Goethe-Institut'ta gerçekleşen gösterimler ve etkinliklerde katılımcıların çoğunluğunu görme engeli olmayan izleyiciler oluşturuyordu. O gün, öğleden sonra, Yol Kenarı filminin yapımcısıyla bir söyleşi gerçekleştirildi. Festival Program Koordinatörü Ezgi Yalınalp, filmin betimlemesi üzerine bir redaksiyon talep ettiklerinden bahsetti. Konuyla ilgili olarak filmin betimlemesini düzeltip düzeltmediklerini öğrenmek amacıyla yönelttiğimiz soruya Yalınalp şu şekilde cevap verdi: “Düzelttik. 'Düzelttik' derken 'onlarınki hatalı' demek istemiyorum. Fakat bazı sahneler vardı. Oyunculukların bilerek, istenerek donuk olduğu sahneler vardı. Onlar biraz dramatize edilmişti. Hata değil aslında 'yorum farkı' diyelim”. 
Tayfun Pirselimoğlu (2018) bir röportajında oyuncuların donuk jestlerinin nedenini şu şekilde anlatır:

Film seyirciyi bir 'oyuna' davet ediyor. Tansu Biçer'in temsil ettiği kimliğin dışındakiler bu oyunun içerisindeki karakterler. Sadece o 'hakiki' bir karakteri işaret ediyor, diğerleri her türlü manalandırılmaktan uzak bir şekilde etrafında dönüyorlar. Film hikâyesi gereği böyle bir yapı üzerine kurulu ve bu da kendi içerisinde bir alegori barındırıyor. Oyunculukların bu kurgu üzerinden tasarlanmış olması muhtemelen izleyicide böyle bir algı yaratıyor ki muradım da odur ${ }^{8}$.

$\mathrm{Bu}$ durumda, Puruli'nin yaptığı redaksiyon doğru bir hamle olarak nitelendirilebilir. Redaksiyon bir çevirinin erek kitleyle buluşmadan önceki en önemli aşamalarından birisidir. Çeviri tamamlandıktan sonra redaktörler erek metni kaynak metinle karşılaştırarak, hem akıcılık ve uygunluk açısından hem de doğru ve eksiksiz bir çeviri olması bakımından kontrol ederler ${ }^{9}$. Sesli Betimleme Derneği de çeviri sonrası kontrol aşamasına önem vermekte ve Engelsiz Filmler Festivali için Puruli Kültür Sanat ile işbirliği yapmaktadır. Bu durumda, Puruli Kültür Sanat, sadece organizatör değil, aynı zamanda filmlerin görme engelli hedef kitleye erişilebilir hâle getirilme sürecinde yer alan başat aktörlerden biridir. Burada, redaktör görevini de üstlenmiştir.

19 Ekim 2018 tarihinde, festivalin üçüncü günü, Goethe-Institut'da gerçekleşen gösterimler ve etkinliklere katılım oranı önceki günlere nazaran daha fazlaydı. İşe Yarar Bir Şey isimli filmin gösterimi yapıldı. Salonda yaklaşık 30 kişi vardı. Aralarında 3 görme engelli vardı. Film başlamadan hemen önce, arkamızda oturan görme engelli olmayan bir izleyici bize "engelsiz, sansürsüz mü demek?" diye sordu. Bir görme engellinin film izleyemeyeceğini düşündüğünü söyledi. Bu konuşma üzerine, engelli olmayan izleyicilerin engellilik algısını ölçmek amacıyla toplamda 5 kadın, 5 erkek olmak üzere 10 izleyiciye şu soruyu sorduk: "Bir görme engelli buradaki filmlere nasıl erişebilir?". 9 kişi bu soruyu, "kendilerine senaryo okunarak veya anlatılarak" diye yanıtlarken, 1 izleyici bu soruyu şu şekilde yanıtladı: "Görme engelli bireyin duyma yetisinin olduğunu düşünürsek, filmler kendilerine sesli olarak anlatılabilir". Bu izleyici, en yakın arkadaşlarından birinin görme engelli olduğunu, dolayısıyla kendisini görme engellilerin dünyasına yakın hissettiğini de belirtti.

Daha sonra gerçekleştirilen söyleşide kendi ülkelerinde benzer film festivalleri düzenleyen organizasyon ekipleri, İngiltere'den Oska Bright Film Festivali ve Almanya'dan Klappe-Auf! Kısa Film Festivali katılım sağlayarak deneyimlerinden bahsetti. Söyleşide Almanya'daki festivalde filmlere sesli betimlemenin canlı olarak gösterim esnasında yapıldığını, ayrıca erişilebilir mekân bulmakta zorlandıklarını öğrendik. Türkiye, maddi kaynak bulmanın zorluklarına değindi. Ayrıca, engelli olmayan kitlede engelli olan kişilere karşı ön yargıların, bir başka deyişle, psikolojik engellerin olduğuna dikkat çekildi. Puruli'den bir kişi, bir önceki sene, çocuklar için yapılan gösterimlerden birinde bir babanın kendi çocuğunun engellilerle film izlemesini istemediğini söylediğini anlattı. Engellerin sadece toplumsal düzenlemelerdeki birtakım

\footnotetext{
${ }^{8}$ https://blog.sinematv.com.tr/2018/05/tayfun-pirselimoglu-filmin-referansi-ruh-hallerimiz/

${ }^{9}$ https://t24.com.tr/k24/yazi/redaktor-ve-editor-ne-is-yapar,340 
eksikliklerden doğmadığını, bireysel algılardan kaynaklanan psikolojik unsurlar olduğunu dile getirdi. Oska Bright Film Festivali organizasyon komitesi de engelli bireylere karşı diğer insanların önyargılı olduklarına vurgu yaparken, maddi kaynak devlet tarafından karşılandığından fon sağlama konusunda herhangi bir problem yaşamadıklarını dile getirdi.

\subsection{Festival Sonrası: Festivalin Basında Yer Alma Şekli ve Anketler}

\subsubsection{Basında Engelsiz Filmler Festivali}

Festival, Cüneyt Özdemir'in sunumuyla CNN Türk ekranlarında, Sabancı Vakfı tarafından desteklenen "Fark Yaratanlar" adlı programda önemli bir girişim olarak yer almıştır. İlgili videoda festivalde filmlerin "görme engelli bireyler için sesli betimleme, işitme engelli bireyler için işaret dili ve ayrıntılı altyazılar eklenerek" gösterime hazır hâle getirilmesine vurgu yapılmış, "otizm dostu ek gösterimler"e dikkat çekilmiş, engelsiz mekânların tercih edildiğinin altı çizilmiştir. Film gösterimleriyle beraber atölyeler ve seminerler gibi kültürel etkinliklerin de herkes için ücretsiz olduğu da özellikle belirtilmiştir. "2013'ten beri engelli engelsiz 20 binin üzerinde kişiye ulaşılan festivalin, hem ülkenin kültürel hayatında hem de engelli bireylerin yaşamlarında kocaman bir fark" ("Engelsiz Filmler Festivali”, t.y.) yarattığı da vurgulanmıştır.

\subsubsection{Anket}

Saha araştırması esnasında, beş görme engelli izleyiciyle karşılaşılmıştır. Sadece iki kişiye gösterimler sonrasında anket uygulanmıştır. Diğer iki kişiye, kendi talepleri doğrultusunda, elektronik posta yoluyla erişilmiştir. Geriye kalan 16 kişi ise bir görme engelli ortaokulu öğrencileridir. Öğretmenlerinin isteği üzerine, anketin ses kaydı kendilerine ulaştırılmış, daha sonra yazılı olarak yanıtlar tarafımıza iletilmiştir ${ }^{10}$.

\subsubsection{Katılımcı Profili}

Ankete 11 kadın ve 10 erkek olmak üzere toplam 21 kişi katılmıştır. Illk olarak, katılımcılara engellilik tipleri sorulmuştur. Görme engellilerin bazıları tamamen göremezken, bazıları ise kısmen görebilmektedir. Görme yetisini kaybetmiş bir kişiyle kısmen görebilen bir kişinin bilişsel becerileriyle doğru orantılı olarak deneyimleri farklı olacağından algıları da değişebilir. Bu hiç göremeyen kişilerin algılama konusunda daima bir adım geride olacakları anlamına gelmez. Tam aksine, Gregory S. Hupp, doktora tezinde yaptığı çalışmada, "hiç göremeyen kişilerin sözel belleklerinin görebilen ve kısmen görebilen kişilere nazaran çok daha iyi" (2003, s. 68) olduğunu kanıtlamıştır. Ancak burada şu noktaya değinmekte fayda var: Algı tek boyutlu bir kavram değildir. Dünyayı sadece görsel ve işitsel kanallar aracılığıyla değil, kullandığımız dil yoluyla da algılarız. Aydın Kızılaslan ve Mustafa Sözbilir, görme engelli bireylerin bilişsel becerileriyle ilgili olarak şu noktaya değinmiştir:

Görme yetersizliği olan çocuklarda, işitsel hafıza becerileri, dil gelişiminde farklı bir rol oynayabilir ve bu da gören çocuklara kıyasla dil kullanma becerilerinin

\footnotetext{
${ }^{10}$ Anket soruları istenildiğinde temin edilebilir.
} 
artmasına neden olabilir. Sözel akıl yürütme becerileri, konuları hızlı bir şekilde değiştirmek zorunda kaldığınızda veya bir kelimenin daha geniş anlamlarını birleştirirken işitsel bellek becerilerinin gerisinde kalıyor gibi görünüyor. Fakat sözdizimi ve gramer, gören çocuklara benzer bir şekilde gelişir görünse de, görmeyen ve az gören dinleyiciler birbirlerinin referanslarını anlamada güçlük çekebilirler. (2018, s. 39)

Buradan yola çıkarak, hedef kitlenin bilişsel beceriler, algı düzeyi ve dil gelişimi yönünden homojen olmadığı sonucuna varılabilir. Dolayısıyla, betimleme yaparken dil kullanımında mevcut çeşitli alternatiflerin arasından sesli betimleme kılavuzlarında işaret edildiği gibi basit ve anlaşılır düzeyde, açık ifadeler kullanmak en doğrusu olacaktır. Anketimizdeki katılımcılardan 15 kişi hiç göremezken, 6 kişi kısmen görebilmektedir.

İkinci olarak, katılımcılara ne zamandan beri görme engelli oldukları sorulmuştur. 15 kişi doğuştan görme engelli olduğunu belirtirken, 6 kişi ise sonradan görme engelli olduğunu ifade etmiştir. Özellikle de renklerin nasıl algılandığını ölçebilmek açısından önemli bir nokta olarak görüldüğünden böyle bir soru sorulmuştur. Sonradan görme engelli bir kişi önceden görmüş olacağından görsel hafızasından getirdiği kadarıyla renkleri hatırlayabilir. Doğuştan görme engelli bir kişinin renkleri hiç tanıyamamış olması, o kişiye betimleme yaparken renklerden hiç bahsedilmeyeceği anlamına gelmez. Betimlemelerde renklere mutlaka yer verilmesi gerektiğine ilişkin olarak Louise Fryer, görüşlerini şu şekilde belirtmiştir: "Renkler görsel niteliklerinin yanı sıra, sonradan görme engelli olan kişilerin hatırlayabilecekleri kültürel ve duygusal çağrışımlara sahiptir... Doğuştan görme engelli kişiler ise görenlerle aynı kültürel çıkarımların bilgisine sahiptir" (2016, s. 68-69). Bir başka deyişle, doğuştan veya sonradan görme engelli olan kişilerle görebilen kişiler aynı toplum içerisinde yaşadıklarından, aynı kültürel kodlara sahiptirler ve renklerin yaptığı çağrışımları aynı şekilde anlayabilirler. Yine de, renklere betimlemelerde yer verilmesinin tam olarak ne ifade ettiğini ölçmek gerekmektedir. Bu amaca uygun olarak da bu soru sorulmuştur.

Katılımcıların yaşlarına bakıldığında ise, görme engelli ortaokulundan katılanların sayısı çoğunluğu oluşturduğundan, katılımcıların 16'sı 18 yaş altındadır. Geriye kalan 5 kişiden 2 tanesi 45-54 yaş aralığında iken, 1 tanesi 65-74, 1 tanesi 55-64, 1 tanesi de 2534 yaş aralığındadır. Aynı şekilde, katılımcıların çoğunluğunu görme engelli ortaokulu öğrencileri oluşturduğundan, katılımcıların çoğunluğunun (16 kişi) eğitim düzeyi ortaokul seviyesindedir. Geriye kalan 5 kişiden 2'si lise, 2'si lisans, 1'i de lisansüstü düzeyde eğitimini tamamlamıştır. Görme engelli hedef kitlenin günlük yaşamda da sesli betimlemeli ürünleri takip edip etmediği sorulduğunda ise, 20 kişinin bu soruya "Evet" yanıtını verirken, 1 kişinin "Hayır" yanıtını verdiği görülmektedir. Bu sorunun sorulmasındaki amaç, hedef kitlenin bilinçli olarak festivale katılıp katılmadığını ölçmektir. Bununla beraber, sesli betimlemeli ürünleri düzenli olarak takip eden izleyicinin kendisine has zevkleri, beklentileri ve yargıları olacaktır. Sesli Betimleme Derneği, "Betimleme Tartışmaları" adında bir platform oluşturarak, burada hem görme engelli olan hem de görebilen tüm bireylerin yanı sıra, sesli betimleme sürecinde yer alan tüm aktörlerin bir araya gelerek, fikir alışverişi yapmalarını sağladı ${ }^{11}$. Görme

${ }^{11}$ Ayrıntılı bilgi için www.sebeder.org sayfası incelenebilir. 
engelliler beklentilerini, düşüncelerini ve eleştirilerini bu platform aracılığıyla dile getirebilmektedirler.

Bir sonraki soruda, bir önceki soruyu "Evet" diye yanıtlayanlar için "Cevabınız 'Evet' ise bu yayınları nerelerden takip edersiniz?" diye sorulmuş, şıklarda ise "Digiturk", "Tivibu", "GETEM (Boğaziçi Üniversitesi Görme Engelliler Teknoloji ve Eğitim Laboratuvarı)", "YouTube”, "Engelsiz Kanal D”, "Engelsiz TRT" ve “Diğer" seçenek olarak verilmiş, birden fazla seçeneğin işaretlenebileceği belirtilmiştir. Verilen cevaplara göre, 16 kişi sadece Engelsiz Kanal D'yi takip ederken, 2 kişi hem GETEM'i hem de Engelsiz Kanal D'yi takip ettiğini belirtmiş, 1 kişi sadece GETEM'i takip ettiğini belirtirken, 1 kişi de hem Digiturk'ü hem de YouTube'u takip ettiğini belirtmiştir. Yani, toplamda, katılımcıların 18 tanesi “Engelsiz Kanal D”yi takip ettiğini belirtirken, 3 tanesi GETEM'i, 1 tanesi Digiturk'ü, 1 tanesi de Youtube'u takip ettiğini belirtmiştir. Tivibu ve Engelsiz TRT'yi takip eden herhangi bir katılımcı yoktur. Bir sonraki, "Önceki yıllarda düzenlenen Engelsiz Film Festivallerine katılmış mıydınız?" tanımlı sorunun cevabında, 17 kişinin festivale ilk defa katıldığı, 4 kişinin festivale önceki yıllarda da katıldığı gözlemlenmiştir.

Katılımcıların festivale neden katıldıkları sorusu birden fazla seçeneğin işaretlenebileceği şekilde hazırlandı. Seçenekler ise şu şekilde verildi: "Engelsiz olması dikkatimi çekti"; "Takip ettiğim metin yazarları bu etkinlikte var"; "Takip ettiğim seslendirmenler bu etkinlikte var"; "Özellikle bazı filmler için geldim"; "Özellikle bazı etkinlikler için geldim"; "Ailemle/arkadaşlarımla dışarıda vakit geçirmek istedim"; "Tavsiye üzerine geldim"; "Daha önce de katılmıştım" ve "Diğer". Verilen cevaplara göre, 2 kişi için festivalin engelsiz olması dikkat çekiciyken, 2 kişi bazı filmler için geldiğini belirtmiştir. 1 kişi tavsiye üzerine gelirken daha önce katılanlardan 1 kişi yine aynı sebeple katıldığını belirtmiştir. 16 kişi ise "Diğer" seçeneğini seçerek, öğretmenlerinin getirdiğini belirtmiştir.

Bir sonraki soru, görme engelli hedef kitlenin festivalden nasıl haberdar olduğuyla ilgiliydi. Birden fazla seçeneği işaretleyebilecekleri seçenekler şu şekilde verildi: "Sosyal medya aracılı̆̆ıla haberdar oldum"; "Mail üzerinden haberdar oldum"; "İ̧̧ arkadaşım/arkadaşım/ailem bana haber verdi"; "Puruli'nin web sitesinden öğrendim"; "Sesli Betimleme Derneği'nin web sitesinden öğrendim"; "Diğer". Verilen cevaplara göre, 2 kişi mail üzerinden haberdar olduğunu belirtirken, 1 kişi yakınları aracılığıyla haberdar olduğunu belirtmiş, diğer 1 kişi GÖRSEM (Görme Engelliler Dayanışma Derneği)'in festivali duyurduğunu belirtirken, 16 kişi ise öğretmenleri aracılığıyla duyduklarını belirtmişlerdir.

Katılımcılara "hangi film veya filmleri izlediniz?" sorusu soruldu. Verilen yanıtlar ise şu şekilde sıralanabilir: Kedi, "Filmin adını hatırlamıyorum", Kelebekler, Pervane, Stalin'in Ölümü, Kedi, "Taliban ile ilgili bir film izledim. Birkaç tane daha izledim ama adlarını hatırlamıyorum", Kar, Kedi, Zebra, Aşkın Gören Gözlere ihtiyacı Yoktur. Katılımcılara "özellikle hangi filmin betimlemesini beğendiniz?" sorusu yöneltilmiştir. 16 kişi Kedi filmini beğendiğini belirtmiş, 1 kişi "adını hatırlamıyorum ama genel olarak beğendim" diye yanıt vermiş; 1 kişi "ben aralarında ayrım yapmıyorum" demiş; 1 kişi "hepsi iyiydi" diye yanıtlamış; 1 kişi ise "Taliban ile ilgili olanı" diye cevap vermiştir.

\subsubsection{Katılımcıların Sesli Betimlemelere İlişkin Görüşleri}


Bob Foss, dramaturjiden bahsederken "konulu filmlerde ve TV oyunlarında söylemek istediğimizi (göstermek istediğimiz dramatik gerçeği) çoğunlukla karakterler aracılı̆̆ıyla söyleriz" (2016, s. 137) diyerek aynı zamanda, film izleme sürecinde olayların sırasını, kurguyu ve konuyu rahatlıkla anlayabilmemizi sağlayan karakterlerin öneminin altını çizer. Karakterlerin yanı sıra diğer görsel ve sessel anlatım araçları da filmi daha iyi kavramamıza yarar. Buradan yola çıkarak, anketimizi "sesler ve müzik", "mekânlar", "nesneler", "karakterler", "renkler" ve "dil kullanımı" olmak üzere altı konu başlığına ayırdık. Beş puanlık geleneksel Likert ölçeğini kullandık ve katılımcılardan beş seçenek arasından kendilerine uyan seçeneği seçmelerini istedik (Tamamen Katılmıyorum Katılmıyorum - Kararsızım - Katılıyorum - Tamamen Katılıyorum).

\section{Sesler ve Müzik}

Bir film özellikle bir şehirde geçiyorsa, diyelim ki bu şehir de İstanbul ise, ilk sahnede çoğunlukla vapur seslerine, denizden gelen dalga seslerine, martıların çığlığına, simitçilerin bağırmalarına ve İstanbul ile özdeşleşen daha birçok görsel ve işitsel öğeye ağırlık verilir. Görsel kısımlar betimlenirken bir yandan da işitsel öğeler akış hâlinde olacağından, hem betimlemeye hem de arka plandan gelen bu işitsel öğelere odaklanmak gerekebilir. Festivaldeki katılımcılara izledikleri filmlerden yola çıkarak, bu konuda ne düşündüklerini öğrenmek için şu ifadeye yer verildi:

\section{Arka plandaki başka seslerden ötürü betimlemeleri tam olarak duyamadım.}

17 kişi, bu ifadeye katılmadığını belirtirken, 2 kişi kesinlikle katılmadığını, 2 kişi ise katıldığını belirtmiştir.

Foss'a göre, "filmde ek olarak müzik kullanılması, görüntüleri vurgulama ya da duygusal içeriğini güçlendirmeye yöneliktir" (2016, s. 45). Örneğin, cenaze törenlerinde çalınan marş, atmosferin ağırlığını vurgularken, bir çizgi filmde veya animasyondaki bir karakter herkesten gizli bir şeyler yaparken, arka planda piyanonun hızlandığı duyulabilir. Görme engeli olan bir birey, böyle bir sahnede işitsel öğe olan müziğe kendiliğinden erişebilirken, görsel öğeye erişebilmek için betimlemeye ihtiyaç duyar. Bunun için de müziğin yer yer kısılması gerekebilir. Bazı bireyler bundan ötürü rahatsızlık duyabilirler. Festivaldeki katılımcılara izledikleri filmlerden yola çıkarak, bu durumun kendilerini ne ölçüde rahatsız ettiğini ölçmek amacıyla, şu ifadeye yer verildi:

Betimlemeden ötürü arka plandaki müziğin yer yer kısılmasından rahatsız oldum.

11 kişi katılmadığını belirtirken, 9 kişi kesinlikle katılmadığını ancak 1 kişi katıldığını belirtmiştir.

\section{Mekânlar}

Hareket ve zamanla birlikte mekân, kurgudaki üç temel öğeden biridir. Amerika ve Avrupa'da yayınlanan sesli betimleme kılavuzlarının tamamı, mekânların betimlenmesi gerektiğine işaret etmektedir. Buna uygun olarak, şu ifadeye yer verilmiştir: 
13 kişi bu ifadeye katıldığını belirtirken, 6 kişi kararsız kalmış, 1 kişi katılmadığını, diğer 1 kişi ise kesinlikle katıldığını ifade etmiştir.

\section{Nesneler}

İtalya, İspanya, Portekiz, Belçika, Polonya ve Almanya'nın katılımıyla gerçekleşen ve Avrupa Birliği tarafından maddi açıdan desteklenen üç yıllık ADLAB (2011-2014) Projesi Raporuna göre, metin yazarı, bir sahneye baktığında, gördüğü nesnenin, sadece görsel olarak mı orada yer aldığına yoksa gerek diyaloglarda gerek üst seste vs. geçip geçmediğine dikkat etmelidir. Bununla beraber, daha açık mı yoksa daha kapalı mı betimleyeceğine karar vermelidir (Remael, Reviers \& Vercauteren, 2015, s. 29). Bu bağlamda, filmlerdeki nesnelerin ne kadar anlaşılır ve dolayısıyla erişilebilir olduğunu ölçmek amacıyla ankette şu ifadeye yer verildi:

\section{Bazı nesneleri anlamadım.}

15 kişi bu ifadeye katılmadığını belirtirken, 2 kişi kesinlikle katılmadığını ifade etmektedir. Bununla birlikte, 3 kişi bu ifadeye katıldığını, 1 kişi ise kararsız kaldığını dile getirmiştir.

Genel bir örnek verilecek olursa, bazen filmlerde "pat", "çat", "küt" gibi sesleri duyarız. Ancak bunların düşme, çarpma, patlama sesleri olmalarıyla beraber hangi nesneye ait olduklarını da belirtmek gerekmektedir. Aksi takdirde, görme engelli izleyicinin zihninde, "bu ne sesiydi?" diye bir soru işareti oluşabilir. Bu noktaya dayanarak, ankette şu ifadeye yer verildi:

\section{Bazı seslerin ne sesi olduğunu anlamadım.}

18 kişi bu ifadeye kesinlikle katılmadığını belirtirken, 2 kişi katılmadığını, 1 kişi ise katıldığını ifade etmiştir.

\section{Karakterler}

"Karakter" denilince, izleyicilerin ilk olarak aklına, bir karakterin kıyafeti, ona özgü bir davranışı veya ses tonu gelebilir. Ancak, görme engelli izleyici açısından önemli olan bir diğer konu da o karakterin yüz ifadeleri (mimikleri) ve hareketleridir (jestler). Sonradan görme yetisini kaybedenler hariç, doğuştan görme engelliler, jest ve mimikleri göremedikleri için gören bireyler gibi başkalarını taklit ederek bunları öğrenemiyorlar ve kullanamıyorlar. Dolayısıyla, yerli bir filmde geçen ve kendi kültürel kodlarının bir parçası olan herhangi bir jest veya mimiğe aşina değillerse, o sahneyi yorumlamakta zorlanabilirler. Öte yandan, dublajlı filmlerde yabancı kültürlere ait birçok ifadeyle de karşılaşılmaktadır. Bu duruma Baş şu şekilde işaret etmektedir:

İzleyicinin bir kültürle ilgili bilgi birikimi ne kadar geniş ve ayrıntılı ise o kültürle ilgili içerikleri de o kadar iyi anlaması söz konusudur. Bu bilgi ise akla gelebilecek herhangi bir konuya ilişkin olabilir, örneğin su şişesinin neye benzediğini veya benzemediğini bilmek bile anlamayı destekleyebilir. (2016, s. 223) 
Dolayısıyla, jest ve mimiklerin olabildiğince anlaşılır olmasında fayda var, denilebilir. Ingiltere'de yayınlanan ITC standartları, eksik bilgi vermeden, öte yandan, yorum yapmadan betimleme yapmanın altını çizer (2000, s. 15). Doğuştan görme engelli bir izleyici jestlerin ve mimiklerin betimlenmesinin ne kadar önemli olduğunun altını çizerek bu konuyla ilgili olarak şunları söylemiştir:

Birisi kaşlarını çattığında veya mutlu gözüktüğünde, bu onun kırmızı elbise veya mavi gömlek giyiyor oluşundan daha önemli. [...] bu çok heyecan verici çünkü insanların jestleriyle ilgili çok şey öğreniyorum çünkü insanların jestleri, bakışları neye benzer bilmiyorum. Görebilen insanların nasıl davrandığını öğreniyorum. (Fryer, 2016, s. 166)

Gert Vercauteren ve Pilar Orero (2013) jestlerin ve mimiklerin duyguları ifade eden sözel olmayan iletişim yolları olduğunun altını çizerken, betimlemecinin görevinin, bunları doğru bir biçimde çevirmek veya aktarmak olduğunu vurgular. Mimiklerin betimlemesinin ne ölçüde erişilebilir olduğuna bakmak için aşağıdaki ifade oluşturulmuştur:

\section{Karakterlerin yüz ifadelerinden bazılarını kafamda canlandıramadım.}

15 kişi bu ifadeye katılmazken, 1 kişi kesinlikle katılmadığını belirtmiş, 2 kişi katılırken, 2 kişi de kararsız olduğunu söylemiştir. Jestlerin betimlemesinin ne ölçüde erişilebilir olduğuna bakmak için ankette aşağıdaki ifadeye yer verilmiştir:

\section{Karakterlerin el kol hareketlerinden bazılarını anlayamadım.}

15 kişi bu ifadeye katılmazken, 1 kişi kesinlikle katılmadığını belirtmiş; 3 kişi katıldığını belirtirken, 1 kişi kesinlikle katıldığını dile getirmiş, diğer 1 kişi ise kararsız kalmıştır.

Karakterler açısından önemli olan bir diğer nokta da o karakterin adıdır. Bazı filmlerde, karakterlerin adları filmin ortalarından itibaren öğrenilir. Görme engeli olmayan izleyici, bu durumun farkına varmasa bile görsel olarak o karakteri aklında tutabilir. Sesli betimlemenin amacı, görme engelli olan hedef kitlenin bir filme herkesle eşit derecede erişmesini sağlamak olduğundan, onun için de karakterin adı filmde geçene kadar söylenmemelidir. Bu durumda yapılacak olan şey, karakterin en belirgin fiziksel özelliklerinden yola çıkarak, uzun saçı kız, fötr şapkalı adam gibi, bir veya iki sıfatla adlandırmaktır. Öte yandan, karakterlerin birbirleriyle olan ilişkilerine de dikkat etmek gerekir. Tüm bunlar göz önünde bulundurularak, ankette şu ifadeye yer verildi:

\section{Konuşanın hangi karakter olduğunu bazı sahnelerde tam çıkaramadım.}

19 kişi bu ifadeye katılmadığını ifade ederken, 1 kişi kesinlikle katılmadığını, diğer 1 kişi ise katıldığını dile getirmiştir. Öte yandan, karakterlerle ilgili olarak şu ifadeye de yer verilmiştir: 
Karakterler arasındaki ilişkileri çözemedim.

10 kişi bu ifadeye katılmazken, 8 kişi kararsız kaldığını, 2 kişi katıldığını, 1 kişi ise kesinlikle katılmadığını dile getirmiştir.

\section{Renkler}

Renklerin görme engellilere anlatılması tartışmalı bir konudur. Dünya genelindeki genel kanı, renklere sesli betimlemede mutlaka yer verilmesi yönünde. Doğuştan görme engelli olan bir birey için bir nesnenin mavi, siyah veya kırmızı olmasının görsel açıdan bir anlamı olmayabilir ancak yukarıda da belirtildiği gibi gören bireylerle aynı toplum içerisinde yaşayan görme engelliler için renkler önem taşır. Öte yandan, görme yetisini sonradan kaybeden bir birey, önceki deneyimlerinden zaten renklerin ne olduğunu bildiği için zihninde canlandırmakta zorlanmayacaktır. Bu hususta ankette şu ifadeye yer verildi:

Renkler benim için önemsizdi ve pek bir şey ifade etmedi.

10 kişi bu konuda kararsız kalırken, 8 kişi katılmadığını dile getirmiş, 2 kişi kesinlikle katılmadığını belirtmiş, 1 kişi ise bu konuya katıldığını ifade etmiştir.

\section{Dil Kullanımı}

Nilgin Tanış Polat metin yazarının bir yandan görsel öğelerin tümünü betimlemek isterken, bir yandan da en uygun boşlukları değerlendirmek çabası içinde olduğunu vurgular. "Bu ikilem, betimleme metninin sözdiziminde ve kelime seçiminde belirleyicidir" (2009, s. 8). Bu yüzden bazen "gözleri fal taşı gibi açılmak", "göz ucuyla bakmak", "can havli ile" gibi deyimler kullanılabilmektedir. Ancak, bunların görme engelli kitleye ne ifade ettiği tartışma konusudur. Bu nedenle ankette de şu ifadeye yer verilmiştir:

\section{Betimlemelerde kullanılan bazı deyimlere aşina değilim.}

13 kişi katılmadığını dile getirirken, 3 kişi kesinlikle katılmadığını, 5 kişi ise katıldığını belirtmiştir. Ayrıca, katılımcıların tümü, aşina olmadıkları başka bir kelime olmadığını bildirmiştir.

\subsubsection{Anket Sonuçları}

\subsubsection{Katılımcı Profili}

Ankete 11 kadın, 10 erkek katılmıştır. Elde edilen bulgulara göre, 15 kişi doğuştan hiç görememektedir. Görme engelliler ortaokulundan gelen toplu katılımdan ötürü, katılımcıların çoğunluğu 18 yaş altı görünüyor fakat yetişkinlere bakacak olursak 45-54 yaş aralığının ağırlıkta olduğu söylenebilir. Katılımcıların eğitim düzeyi ortalama seviyededir. Ayrıca, sesli betimlemenin ne olduğunu bilen ve bu konuda deneyimli ve birikimli bir izleyici kitlesi olduğundan bahsedilebilir. Elde edilen bulgulara göre, görme engelli izleyici kitlesi arasında Engelsiz TRT'yi takip eden kimse bulunmamaktadır. 
Engelsiz TRT'de sadece Sesli Betimleme Derneği değil, aynı zamanda Moroğlu Engelsiz Sinema Kültür ve Sanat Derneği de bir diziyi erişilebilir hâle getirmektedir. Bu sonuçlara göre, özellikle de Moroğlu'nun çalışmalarını takip eden izleyici kitlesi yoktur, diyebiliriz. Ayrıca elde edilen bulgulara göre, en çok Engelsiz Kanal D takip edildiğinden görme engelli hedef kitlesinin dizi takipçisi olduğu söylenebilir. Öte yandan, Tivibu’yu kimse takip etmezken, Digiturk üyeliği olan sadece bir kişi bulunmaktadır. Bunun sebebi, Engelsiz Kanal D’nin internetten kolaylıkla erişilebilir olması iken, Tivibu ve Digiturk gibi platformların ücretli aboneliği şart koşması olabilir. Ankete göre, katılımcıların çoğunluğu festivale ilk defa katılmışlardır. Verilen çeşitli yanıtlara göre, festival çeşitli kanallar yoluyla hedef kitleye erişmeyi başarmıştır. Cevaplarda çeşitlilik söz konusu olsa da en çok izlenen belgesel film Kedi olmuştur. Verilen yanıtlara göre yapılan sesli betimleme çalışmaları genel olarak beğenilmiştir.

\subsubsection{Katılımcıların Sesli Betimlemelere İlişkin Görüşleri}

Görme engelli izleyiciler hem betimlemelere hem de arkadan gelen diğer seslere aynı anda odaklanmakta zorlanmamaktadırlar. Mekân betimlemeleriyle ilgili görüşlere bakacak olursak, her ne kadar çoğunluk betimlemelerin yeterince erişilebilir olduğunu düşündüğünü belirtmiş olsa da, katılımcıların belirleyici bir kısmının kararsız kalmış olması bu konuda soru işareti bırakmaktadır. Bu konuyla ilgili olarak genelleme yapmak yanlış olabilir çünkü söz konusu olan mekân çok fazla ayrıntıya sahip olabileceği gibi filmde yer alan diyaloglar arası boşluklar önemli noktaları vermek için yeterli olmayabilir. Sesli Betimleme Derneği'nin çalışmalarına baktığımızda, betimlemelere oldukça ayrıntılı yer verildiği tespit edilebilir. Nesnelerin yeterince erişilebilir olduğu gözlemlenmiştir. Karakterlerin yüz ifadelerinin ve el kol hareketlerinin betimlemesine gelindiğinde, her ne kadar çoğunluk yeterince erişilebilir olduğunu ifade etmiş olsa da, herkesten farklı cevaplar alındığı gözlemlenmiştir. Daha öncesinde de işaret edildiği gibi, görme engelli bireyler jestleri ve mimikleri göremediklerinden, kendileri de kullanamıyorlar. Günlük hayatlarında mevcut olmayan bir şey her ne kadar erişilebilir hâle getirilse de kimi zaman bir şey ifade etmeyebilir. Öte yandan, Sesli Betimleme Derneği'nin hâlihazırdaki çalışmalarına bakıldığında, tıpkı diğer öğelerde olduğu gibi karakter betimlemelerinde de sadece ekrandaki görüntüyü eşdeğer sözcüklerle aktarmadıkları, kimi zaman sıfatlarla bunları öyküleştirdikleri görülebilir. Örneğin, TRT'deki Halka isimli dizinin ilk bölümünde yer alan karakterin yüz ifadesi şu şekilde betimlenmiştir: "Sakin bir gerginliği var, yüzünde korku veya tedirginlik yok" ("Halka”, t.y.). Bu örnekte görüldüğü gibi, zaten soyut olan duygular yine soyut olarak anlatılmıştır. Bu ve benzeri tercihler görme engelli izleyiciler açısından zorlayıcı olabilir. Anket sonuçları, aynı durumun karakterler arasındaki ilişkilerin erişilebilirliği için de geçerli olduğunu göstermektedir.

Renkler konusunda ise sonuçlar, bu konunun görme engelli izleyici kitlesi arasında da tartışmalı olduğunu gösteriyor. Joel Snyder, betimlemelerde renklere mutlaka yer verilmesi gerektiğinin altını şu şekilde çizmiştir:

Doğuştan görme engelli olan veya erken yaşta görme yetilerini kaybeden kişiler renkleri göremeseler de her bir rengin ilişkilendirildiği şeye göre önemini anlıyorlar. Yeşili görmüyor olabilirler ama dokunduklarında ve kokladıklarında bir şeyler ifade eden çiçek saplarının, yaprakların ve çimlerin rengi olduğunu biliyorlar. (2010, s. 12) 
Renklerin sesli betimlemede yer alması bir yana, nasıl betimlenmeleri gerektiği de ayrı bir tartışma konusu olmuştur. Örneğin, Fransa'da yayınlanan La Charte de l'audio description (Gonant \& Morisset, 2008) adlı kılavuz renkleri betimlerken mutlaka bir sıfatla desteklenmeleri gerektiğini belirtmektedir. Türkiye'de ise renklerin sadece adları belirtilmektedir. Dil kullanımı açısından ise, betimlemelerdeki deyimlerin anlaşılır olup olmadığı hususunda görüşleri alınan katılımcılar herhangi bir güçlük yaşamadıklarını ve betimlemelerde sıklıkla kullanılan deyimlerin filmlerin takibinde akışı engellemediğini belirtmişlerdir.

\section{Sonuç}

Engelsiz Filmler Festivali 2013 yılında engelli bireylerin kültürel ve sanatsal faaliyetlere katılmalarını sağlamak amacıyla başta Ankara'da düzenlenmeye başlamış, 2017 yılından itibaren de Eskişehir ve İstanbul'u da bu amaç doğrultusunda gündemine almıştır. Organize edildiği ilk yıldan itibaren yetişkinlere ve çocuklara yönelik olarak hem film gösterimleri hem de senaryo ve canlandırma atölyeleri düzenleyerek engeli olan ve olmayan herkesi bir araya toplamayı hedeflemiştir. Bunu da filmlerine işaret dili, ayrıntılı alt yazı ve sesli betimleme ekleyerek ve aynı zamanda da bu filmlerin gösterimlerini orijinal sesleriyle yaparak gerçekleştirmiştir. Öte yandan, festivale ev sahipliği yapan mekânların engelsiz olmasına, yani engellilerin oraya ulaştıklarında sorun yaşamayacakları yerler olmasına dikkat edilmiştir. Ayrıca, bu faaliyetler festival boyunca ücretsizdir. Tüm bu düzenlemeler tesadüfî olarak değil, festivalin ilk yıllarından itibaren katılımcılarından gelen eleştiriler doğrultusunda yapılmıştır.

Bu çalışmanın amacı, 17-21 Ekim 2018 tarihleri arasında Ankara'da düzenlenen Engelsiz Filmler Festivali'nin görme engelli hedef kitlesi açısından ne kadar erişilebilir olduğu sorusuna cevap vermektir. Bu amaca uygun olarak, festival öncesini, festival alanını ve festival sonrasını kapsayan bir araştırma yapılmıştır. Çalışmanın ilk basamağında, festivalin hedef kitleye birçok kanalla duyurulduğu tespit edilmiştir. Festival basında geniş yer tutmuş, gerek otizm dostu olmasına gerekse işaret dili, alt yazı ve sesli betimleme teknikleriyle engelsiz festival oluşuna dikkat çekilmiştir. Festival, organizasyon komitesinin ve Sesli Betimleme Derneği'nin sosyal medya hesaplarında duyurulmuş ve "engellerin ve sınırların aşılmak için var olduğunu gösteren yapımlar" başlığıyla ön plana çıkarılmıştır. Sesli Betimleme Derneği'ne ait, görme engellilerle sesli betimlemeli filmlerin listesini paylaşan ve aynı zamanda da engelliler arasında bir tartışma platformu olan "Betimleme Tartışmaları” mail grubunda da afiş ve gösterim programıyla birlikte festivalin duyurusu yapılmıştır. Ayrıca, başta festivale ev sahipliği yapan mekânlar olmak üzere, şehrin birçok noktasında afişlerin asılı olduğu gözlemlenmiştir.

Festival alanında afiş, kılavuz ve gösterim programının görme engelliler için ne derece erişilebilir olduğu incelenmiştir. Bu metinlere hem sosyal medyadan hem de organizasyon komitesiyle Sesli Betimleme Derneği'nin internet sitelerinden 
erişilebiliyor. Ayrıca, ekran okuyucularla $p d f$ formatındaki dosyalara erişilemediğinden, görme engelliler için word formatındaki haliyle de gösterim programına internet sitesinde yer verilmiştir. Etkinlik alanında, girişte gösterim programı ve kılavuz Braille alfabesiyle basılı hâlde temin edilebilmiştir. Etkinlikteki tüm filmler sesli betimlemeli olarak erişilebilir hâle getirilmiştir. Almanya'da düzenlenen Klappe-Auf Film Festivali'nde betimlemeler eş zamanlı olarak gösterim esnasında yapılmaktadır. Bu açıdan engelsiz erişim konusunu oldukça önemseyen ve sesli betimleme çalışmalarını titizlikle yürüten Almanya'da festivaller konusunda farklı bir tutum olduğu görülmektedir. Türkiye'de betimlemelerde sadece Sesli Betimleme Derneği değil, gerektiğinde Puruli Kültür Sanat da redaksiyon aşamasına dâhil olmaktadır. Eş zamanlı sesli betimlemelerde yapılacak olan herhangi bir hatanın geri dönüşü olmayacağı gibi eksiklikler sebebiyle de filmin özündeki mesaj seyirciye ulaşmayabilir.

Katılımcıların ilgisini araştırmak amacıyla film gösterimlerine ve etkinliklere katılım sağlanmıştır. Tercih edilen festival alanlarına erişim kolay olduğu gibi, mekân içi erişilebilirlik de tüm engellilere göre düzenlenmiştir. Ancak, burada dikkat çeken nokta, görme engelli katılımcıların sayısının az olmasıdır. Bunun iki sebebi olabilir. İlki, görme engelli bireylerin toplumda var olan ön yargılar nedeniyle dışarı çıkıp yeterince sosyalleşememesi olabilir. Muhtaç insan muamelesi görmek onları rahatsız etmektedir. İkinci olarak, bu filmlerin hepsinin ses dosyaları, festival bitiminde belli bir süre geçtikten sonra GETEM'e yüklenmektedir. Üyelik yapıldığı takdirde, ücretsiz olarak yararlanılmasından ötürü bu platform, etkinliğe nazaran daha fazla tercih edilebilir. Burada dikkat çeken bir başka nokta ise, görme engelli olmayan izleyicilerin, görme engellilerin de filmlere erişebileceğinden habersiz olmalarıdır. Bu durum sesli betimleme gibi erişilebilirlik çalışmalarının görme engeli olmayanlar tarafından pek bilinmediğine işaret etmektedir. Ayrıca "engelsiz" kavramından "sansürsüz" gibi başka bir anlam çıkaranlara da rastlanmıştır. Bu algı, engellilik, erişilebilirlik, engellerin aşılması gibi kavramların henüz yerleşmediğinin göstergesidir. Tüm bunlara rağmen, görme engeli olmayan katılımcıların oranının fazla olmasının sebebi etkinliklerin çeşitli ve ücretsiz olmasıdır.

Festival sonradan basında "kültürel hayata eşit katılım" ilkesinden yola çıkılarak, erişilebilir mekânlarda, başta sesli betimleme olmak üzere engelleri ortadan kaldıran tekniklerle sunulan ücretsiz kültürel etkinliklerinden ötürü "fark yaratan" olarak yer almıştır. Anket sonuçlarına bakıldığında ise, doğuştan görme engelli kitlenin çoğunlukta olduğu ortaya çıkmıştır. Anket, "sesler ve müzik", "mekânlar", "nesneler", "karakterler", "renkler" ve "dil kullanımı" olmak üzere altı konu başığına ayrılmış ve genel olarak tüm bu öğelerin sesli betimlemeleriyle hedef kitlenin beklentileri arasında herhangi bir uyuşmazlık olmadığı sonuçlara yansımıştır. Ancak, yüz ifadeleri, el kol hareketleri ve aralarındaki ilişkiler açısından karakterlerin ve renklerin betimlemeleri konusunda verilen cevaplardan, erişilebilirlik bu noktalarda tartışmalı görünmektedir. Böyle bir sonucun çıkmasında en önemli etken, katılımcıların çoğunluğunun doğuştan görme engelli olmasıdır. Yüz ifadeleri ve el kol hareketleri, yani beden dili her topluma ve her kültüre göre değişkenlik gösterdiği gibi, o toplumda bulunan insanlar kimi hareketleri birbirlerinden görerek ve birbirlerini taklit ederek öğrenirler. Benzer durum renkler için 
de geçerlidir. Doğuştan görme engelli olan kişilerin bu şansları olmadığından betimlemelerin anlaşılmasında da kimi zaman zorluklar yaşanmaktadır. Bu zorluğun yaşanmasında hâlihazırda soyut olan bu kavramların yine soyut ifadelerle anlatılması da yatmaktadır. Ancak betimlemeleri mümkün kılan unsurun diyaloglar arasındaki boşluklar olduğu da unutulmamalıdır. Yani, süre kısa olduğundan, örneğin "kafasını sola çevirdi, kaşlarını yukarı kaldırdı ve dudaklarını kıvırarak gözlerini kıstı” demek yerine "alay edercesine baktı" demek zorunda kalınmış olunabilir. Her ne kadar betimlemelerde soyut ifadelere yer vermek yerine, somutlaştırmaya ağırlık verilmesi önem arz etse de, görme engelli bireylerin söylem evrenlerinin zengin olması da ayrıca önemlidir. Bu da ancak okullarda verilecek olan eğitimin zenginliğiyle mümkün olacaktır. Ayrıca görme engelli bireyler arasındaki eğitim ve kültürel altyapıyla ilgili farklılıklar onların betimlemeleri farklı yorumlamalarına neden olabilir.

Sonuç olarak, Engelsiz Filmler Festivali'nin görme engelli hedef kitlesi açısından yeterince erişilebilir olduğu gözlemlenmiştir. Ayrıca, "bir arada yaşama ilkesini hayata geçirme" amacıyla filmleri erişilebilir hâle getiren Sesli Betimleme Derneği ve "kültürel hayata eşit katılım" ilkesiyle bu erişilebilirliği kamusal alana taşıyan Engelsiz Filmler Festivali ve organizasyon komitesi Puruli Kültür Sanat, bu festivalle erişilebilirlik uygulamalarında önemli birer aktör olduklarını kanıtlamışlardır.

Bu çalışma Türkiye'de sesli betimleme alanında hedef kitle odaklı ilk çalışma olma özelliğini taşır. Görme engelli hedef kitlenin fikirlerini almak, sesli betimleme çalışmalarının kalitesi bakımından önemlidir. Sesli betimlemeyi yapan gören bireylerdir ancak hedef kitle görme engelli bireylerdir. Sesli betimleme sürecinde çevirmenlerin öncelikle görmemenin ne anlama geldiğinin farkında olmaları gerekmektedir. Bu durumun anlaşılabilmesi ancak görme engellilerin fikirlerine yer vererek, onlarla ortak yaşam alanlarını paylaşarak mümkün olabilir. Öte yandan, bu konuda duyarlılık geliştirmek için Baş’ın çalışmasında (2019) önermiş olduğu gibi çevirmenler sesli betimleme eğitimleri esnasında filmleri bir süreliğine görme engelli bireyler gibi sesli betimlemeli olarak, sadece işitsel kanallar aracılığıyla izleyebilirler. Bu araştırmada, hedef kitlesinde görme engelliler de olan Engelsiz Filmler Festivali vesilesiyle görme engelli hedef kitle ile bir araya gelinmiş, sesli betimlemelerin kalitesi konusunda fikirleri alınmış ve sonuç olarak da, görme engellilerin jest ve mimikler ile renklerin betimlemelerini anlamada zorlandıkları ortaya çıkmıştır. Dolayısıyla jest ve mimikler ile renklerin görme engelli bireylerin söylem evrenine nasıl katılması gerektiği, sesli betimlemede bunların nasıl erişilebilir hâle getirilebileceği araştırılabilir. Bu çalışmanın görme engelli olmayan izleyicilerle ilgili olarak ortaya çıkardığı diğer bir gerçek, toplumumuzda "engellilik", "erişilebilirlik", "sesli betimleme" gibi kavramların net bir biçimde bilinmediğiyle ilgilidir. Bu eksiklik kimi zaman psikolojik engellere ve ön yargılarla dolu toplumsal algıya da yol açmaktadır. Bu nedenle önce toplum "engellilik" ve "erişilebilirlik" konusunda bilinçlendirilmelidir. Sesli betimleme yapan Sesli Betimleme Derneği ve festival için bu sürece dâhil olan Puruli Kültür Sanat bu bilince sahip olan aktörlerdir. Ancak erişilebilir hâle getirilecek materyal sayısının çokluğu 
aktörlerin artması gereksinimini de beraberinde getirmektedir. Aktörlerin sayısı arttıkça yapılacak karşılaştırmalı çalışmalar sayesinde daha kaliteli ürünler elde edilebilecektir. 


\section{Kaynakça}

6. Engelsiz Filmler Festivali, Seyircilerini "Otizm Dostu Gösterim"lerine Davet Ediyor. (13 Ağustos 2018). Erişim Tarihi: 11 Ekim 2018. Erişim Adresi: https://www.medyakafa.com/eglence/otizm-dostu-gosterim/

Baş, N. (2016). Görsel-işitsel çeviri, dublaj ve sesli betimleme. Ankara: Grafiker Yayınları.

Baş, N. (2019). Görenler sesli betimlenmiş bir filmi nasıl anlar? Sesli betimleme ile ilgili bir alımlama çalışması denemesi. Çeviribilim ve Uygulamaları Dergisi, 26, 37-59.

Dalbudak, Ş. (2019). İşitme engelliler için dil içi ayrıntılı altyazı uygulamaları. Çeviribilim ve Uygulamaları Dergisi, 26, 60-76.

Engelsiz Filmler Festivali 6. kez sinemaseverlerle buluşuyor. (7 Ağustos 2018). Erişim Tarihi: 11 Ekim 2018. Erişim Adresi: https://www.haberturk.com/engelsiz-filmler-festivali-6-kezsinemaseverlerle-bulusuyor-2093437

Engelsiz Filmler Festivali 6. kez sinemaseverlerle buluşuyor. (7 Ağustos 2018). Erişim Tarihi: 17 Ekim 2019. Erişim Adresi: https://t24.com.tr/haber/engelsiz-filmler-festivali-6-kezsinemaseverlerle-bulusuyor,673939

Engelsiz Filmler Festivali üç şehirde. (7 Ekim 2018). Erişim Tarihi: 17 Ekim 2019. Erişim Adresi: http://www.milliyet.com.tr/gundem/engelsiz-filmler-festivali-uc-sehirde-2756707

Engelsiz Filmler Festivali. (26 Ekim 2018). Erişim Tarihi: 20 Şubat 2019. Erişim Adresi: http://www.farkyaratanlar.org/site/tr/fark_yaratanlar/176/Engelsiz-FilmlerFestivali.html

engelsizfestival. "Engelsiz Filmler Festivali". Instagram, 28 Eylül 2018, https://www.instagram.com/p/BoQ7IBUB9yn/

Foss, B. (2016). Sinema ve televizyonda anlatım teknikleri ve dramaturji (M.K. Gerçeker, Çev.). İstanbul: Hayalperest Yayınevi.

Fryer, L. (2016). An introduction to audio description: A practical guide. Londra ve New York: Routledge Taylor \& Francis Group.

Gonant, F.,\&Morisset, L. (2008). La Charte de I'audio description. Paris: Ministère des Affaires Sociales.

Güven, M. (2018). Sesli betimleme araştırmalarında güncel yönelimler. Dilbilim Araştırmaları Dergisi, 2, 107-127. doi: http://dx.doi.org/10.18492/dad.424635

Hakkında. (t.y.). Erişim Tarihi: 1 Şubat 2019. Erişim Adresi: http://www.engelsizfestival.com/tr/33599/HAKKINDA

Halka. (t.y.). Erişim Tarihi: 5 Şubat 2019. Erişim Adresi: http://engelsiztrt.tv/video.aspx?LIST_ID=PL_VIYAL9VnIWvmpPKKcYjCfm99_vNOdX\&VIDEO_ID=A5y3x3bTMBw

Hupp, G. S. (2003). Cognitive differences between congenitally and adventitiously blind individuals. Kuzey Teksas Üniversitesi'nde Basılmış Olan Doktora Tezi. Erişim Adresi:http://citeseerx.ist.psu.edu/viewdoc/download?doi=10.1.1.905.1055\&rep=rep1 \&type=pdf

ITC Guidance on Standards for Audio Description. (2000). Erişim Tarihi: 26 Temmuz 2018, http://audiodescription.co.uk/uploads/general/itcguide_sds_audio_desc_word3.pdf. 
Jakobson, R. (1959). On linguistic aspects of translation. On Translation, 23, 232-239. Boston: Harvard University Press.

Kızılaslan, A. \& Sözbilir, M. (2018). Görme yetersizliği olan öğrencilerin bilişsel becerileri ve psikolojik deneyimleri üzerine bir derleme. Pamukkale Üniversitesi Sosyal Bilimler Enstitüsü Dergisi, 31, 29-43. doi: 10.30794/pausbed.414613

Kruger, J-L. (2010). Audio narration: Re-narrativising film. Perspectives, 18(3), 231-249. doi: 10.1080/0907676X.2010.485686

Mithat Alam Film Merkezi. (t.y.). Erişim Tarihi: 17 Ekim 2019. Erişim Adresi: http://www.mafm.boun.edu.tr/kategori/48/sesli-betimleme-ogrenci-grubu

Nedir. (t.y.). Erişim Tarihi: 22 Ocak 2019. Erişim Adresi: http://www.puruli.co/tr/36128/NEDIR

Okyayuz, A. Ş. \& Kaya, M. (2016). Erişim çağında azınlığa gönderim ve bir çeviri türü olarak sesli betimleme. The Journal of Academic Social Science Studies, 51, 15-32. doi: http://dx.doi.org/10.9761/JASSS3803

Okyayuz, A. Ş. (2017). Sesli betimlemenin çeviribilim sınıflarında tanıtımı için bir eğitim bileşeni önerisi. Turkish Studies, International Periodical for the Languages, Literature and History of Turkish or Turkic, 12(22), 559-586. doi: http://dx.doi.org/10.7827/TurkishStudies.12325

Otizm dostu "Engelsiz Filmler Festivali" başlıyor. (31 Ağustos 2018). Erişim Tarihi: 11 Ekim 2018. Erişim Adresi:https://www.timeturk.com/otizm-dostu-engelsiz-filmler-festivalibasliyor/haber-952526

Redaktör ve editör ne iş yapar? (3 Eylül 2015). Erişim Tarihi: 11 Ekim 2018. Erişim Adresi:https://t24.com.tr/k24/yazi/redaktor-ve-editor-ne-is-yapar,340

Remael, A., Reviers, N., \& Vercauteren, G. (2015). Pictures painted in words: ADLAB audio description guidelines. Trieste: EUT Edizioni Università di Trieste.

Resim 1. [Engelsiz Filmler Festivali 2018]. (2018). Erişim Tarihi: 20 Şubat 2019. Erişim Adresi: http://www.engelsizfestival.com/upload/Node/33614/pics/afis_.300px.jpg

Resim 2. [2018 Engelsiz Filmler Festivali Basılı Gösterim Programı]. (2018). Erişim Tarihi: 11 Ekim 2018. Erişim Adresi: http://www.engelsizfestival.com/tr/37283/FILM-PROGRAMI

Resim 3. [2018 Engelsiz Filmler Festivali Word Formatında Gösterim Programı]. (2018). Erişim Tarihi: 11 Ekim 2018. Erişim Adresi: http://www.engelsizfestival.com/tr/37283/FILMPROGRAMI

Sesli Betimleme Derneği. (t.y.). Erişim Tarihi: 17 Ekim 2019. Erişim Adresi: http://www.mafm.boun.edu.tr/kategori/48/sesli-betimleme-ogrenci-grubu

Snyder, J. (2010). Audio description guidelines and best practices. Erişim Tarihi:22 Eylül 2018, http://docenti.unimc.it/catia.giaconi/teaching/2017/17069/files/corsosostegno/audiodescrizioni

Tanış Polat, N. (2009). Çeviribilim ve dilbilim bağlamında Türkiye'de sesli betimlemenin yeri ve önemi. Dilbilim Araştırmaları, 1, 1-10. Erişim Tarihi: 1 Eylül 2016, http://dad.boun.edu.tr/issue/24369/258312 
Tayfun Pirselimoğlu: Filmin referansı ruh hallerimiz. (21 Mayıs 2018). Erişim Tarihi: 11 Ekim 2018. Erişim Adresi:https://blog.sinematv.com.tr/2018/05/tayfun-pirselimoglu-filminreferansi-ruh-hallerimiz/

Vercauteren, G., \& Orero, P. (2013). Describing facial expressions: Much more than meets the eye. Quaderns: revista de traducció, 20, 187-199. 